\author{
St ud i P hilos o p hic a \\ Wr a t is l a vie n s i a \\ vol. XIV, fasc. 4 (2019) \\ DOI: $10.19195 / 1895-8001.14 .4 .3$
}

\author{
MARCIN PIETRZAK \\ ORCID: 0000-0003-3925-9215 \\ Uniwersytet Opolski
}

\title{
Uwagi o mowie cynicznej. Kallikles i Trazymach jako mówcy cyniczni
}

\author{
Notes on Cynical Speech. Callicles and Thrasymachus \\ as Cynical Speakers
}

\begin{abstract}
Cynical speech is a proper form of manifestation of what we call cynicism. It takes the form of a persuasive strategy which assumes the achievement of the rhetorical consubstantiation of a cynical speaker and her/his auditorium. Cynical speech is a game that takes place between three sides: a cynical speaker posing as an immoralist, a moralist and an auditorium, the acquisition of which is the aim of both interlocutors. At the outset, the cynical speaker gives the identity of naive dilettantes' to both the members of the auditorium and the moralist and then tries to persuade the audience to side with him and take on the role of the students of a cynical expert. This is what can be described as cynical modulation. In its course, the initial opposition of a professional versus dilettante turns into an opposition of master versus student, while the unattractive identity of a dilettante is transferred to a moralist. In this way, the speaker achieves what Kenneth Burke thinks is the right goal for any rhetorical act: the speaker's consubstantiation with the auditorium. This process is presented based on the example of the disputes between Socrates, as a moralist on the one hand, and sophist-politicians Thrasymachus and Callicles, who personify the type of cynical speakers, on the other. The analysis of cynical speech carried out in the paper leads to an indication of some basic features of this way of speaking, as well as the relationship that exists between them and the content of viewpoints voiced by cynical speakers. These viewpoints have been described as aristocratic democratism and people's anti-democratism. These are two forms of what has been described as the cynical counter-ideal. The adoption of these positions is an indirect expression of the same
\end{abstract}


systematic ambiguity that lies in the form of cynical speaking, which belongs to the very essence of cynicism as a cultural phenomenon.

Keywords: cynicism, rhetoric, Kenneth Burke, moralism, immoralism, cynical modulation

Niniejszy artykuł jest próbą zrozumienia pewnego sposobu mówienia, który określam mianem mowy cynicznej. Jako przykładami posługuję się postaciami sportretowanych przez założyciela Akademii sofistów polityków Trazymacha i Kalliklesa, których stawiam w roli mówców cynicznych. Na podstawie analizy ich wypowiedzi dokonuję rekonstrukcji podstawowej struktury cynicznego sposobu mówienia i wskazuję na istotny dla jego zrozumienia kontekst dramatyczny, którego zrozumienie, jak twierdzę, jest niezbędne przy próbie zbudowania koncepcji wyjaśniającej efekt retoryczny, jaki daje mowa cyniczna, a także pozwala na osadzenie rozważań nad cynicznością w ramach badań nad filozofią moralności.

Badania nad cynizmem prowadzone są zazwyczaj w paradygmacie, zgodnie z którym istoty tego fenomenu należy doszukiwać się raczej w treści niż w formie mowy cynicznej. Michał Głowiński w artykule zamieszczonym na łamach „Etyki” pisał:

Cynizm nie stanowi zjawiska językowego w ścisłym sensie, podobnie jak nie stanowi go kłamstwo. Nie ma - jak się zdaje - mowy, która byłaby cyniczna z natury, niezależnie od okoliczności, w jaki by ją realizowano, poza konkretnym miejscem i poza konkretnym czasem ${ }^{1}$.

W moich analizach przyjmuję założenie, jeśli nie sprzeczne, to przynajmniej przeciwne względem poglądu przedstawionego w cytacie. Moim zdaniem cynizm czy cyniczność są przede wszystkim zjawiskami komunikacyjnymi i choć nie są one być może zjawiskiem językowym w ścisłym sensie, to jednak ich natura ujawnia się w pewnym sposobie mówienia i tylko jako taka może zostać zbadana. Być może zatem cynizm nie jest zjawiskiem ściśle językowym, ale z pewnością jest zjawiskiem, które ujawnia się na poziomie mówienia. Stosowane przez językoznawców rozróżnienie języka i mowy pozwala rozjaśnić to zagadnienie. Cyniczność jest przede wszystkim właściwością pewnego sposobu mówienia i jako taka przejawia się w działaniach językowych, które określam mianem mowy cynicznej. Aby zrozumieć mówienie cyniczne, nie wystarczy jednak odwołać się do pojęcia stylu mówienia, jak to dalej czyni Michał Głowiński² , ale trzeba odwołać się do szerszego kontekstu wypowiedzi, na który składają się audytorium i interlokutorzy cynicznego mówcy. To zaś każe mi przenieść analizy cyniczności na grunt retoryki, która stanowi dogodny heurystyczny punkt wyjścia dla badań nad omawianym fenomenem, a z którego dopiero można przenieść analizy na grunt filozofii moralności.

W moim artykule wychodzę od pojęcia paradoksu cynicznego, aby kolejno wprowadzać pojęcia modulacji cynicznej, immoralizmu cynicznego jako kontrstra-

\footnotetext{
${ }^{1}$ M. Głowiński, O mówieniu cynicznym, „Etyka” 37 (1997), s. 17.

${ }^{2}$ Ibidem, s. 19.
} 
tegii stosowanej przez cynicznego mówcę i kontrideału cynicznego, które to pojęcie służy do opisania ethosu, jakim posługuje się mówca cyniczny w celu zjednania sobie publiczności.

\section{Czym jest paradoks cyniczny?}

Mianem paradoksów Grecy określali wszystko to, co wychodziło poza ramy zwyczajnego biegu spraw i co jako takie wzbudzało zdziwienie, zachwyt albo nawet przerażenie $^{3}$. Na miano paradoksalnych mogli zasłużyć wybitni sportowcy lub artyści ${ }^{4}$, którzy swoimi czynami wzbudzali zachwyt i niedowierzanie. „Paradoksalny” to w tym znaczeniu również tyle co cudowny i niezwykły. Stąd tėz ten, kto opowiadał historie niewiarygodne i cudowne, zasługiwał na miano „paradoksografa". Pojęcie paradoksu nabrało szczególnego znaczenia w toku kształtowania się pierwszych szkół filozoficznych, których członkowie, chcąc dać wyraz głoszonym przez siebie poglądom, posługiwali się często stwierdzeniami, których treść pozostawała w sprzeczności z potocznie akceptowanymi presupozycjami dotyczącymi bądź to sfery faktów, bądź przyjmowanych sądów wartościujących. Do pierwszego z tych rodzajów należą słynne antynomie Zenona z Elei, w których głosił on niemożliwość wszelkiego ruchu, a także poglądy jego nauczyciela Parmenidesa, odmawiającego rzeczywistego istnienia wielości i głoszącego naukę o absolutnej jedności bytu. Do drugiej kategorii należą wszelkie tezy filozoficzne, których treść nie zgadza się z potocznym poglądem moralnym. Samo słowo ,paradoks" w odniesieniu do poglądów filozoficznych weszło do powszechnego użytku nieco później, wraz z pojawieniem się szkoły stoickiej, której naukę moralną w II wieku p.n.e. Cyceron streścił w dziele pod znamiennym tytułem Paradoxa stoicorum. Dla ilustracji warto przytoczyć listę omówionych przez słynnego mówcę paradoksów stoickich: (1) jedynym dobrem jest cnota, (2) ta zaś wystarcza do szczęśliwego życia. (3) Wszelkie występki są sobie równe. (4) Każdy głupiec jest szaleńcem (5) i niewolnikiem, zaś mędrzec jedynie jest człowiekiem wolnym (6) i bogatym. Stwierdzenia te musiały brzmieć dziwacznie nie tylko dla niewyrobionego filozoficznie ucha Greka lub Rzymianina, ale budzą podobne uczucia również dzisiaj, co stanowi o ich nieprzemijającej wartości i czyni z nich część kanonu philosophia parrenis.

Aby odpowiedzieć na pytanie, dlaczego filozofowie lubią posługiwać się w swoich naukach stwierdzeniami dającymi afekt paradoksalności, trzeba wskazać na kulturową genealogię, która opisuje powstanie filozoficznego poglądu na świat, jako wyłaniającego się ze sposobu myślenia charakterystycznego dla epoki mędrców, gdy podstawowym sposobem wyrażania prawd była zagadka, której „przypisywano w cywilizacji archaicznej Grecji wielkie znacznie, zwłaszcza, że dostrzegano jej związki ze źródłami mądrości”. Gdy mędrzec wypowiada zagadkę, rzuca

${ }^{3}$ M.J. Hyde, Paradox: The Evolution of figure of Rhetoric [w:] Rhetoric 78: Proceedings of Theory of Rhetoric: An Interdisciplinary Conference, R.L. Brown Jr., M. Steinmann Jr (eds.), Minneapolis 1979, s. 202.

${ }^{4}$ Por. Epiktet, Diatryby. Encheiridion, tłum. L. Joachimowicz, Warszawa 1961, III, 18, s. 172.

${ }^{5}$ Zob. H.G. Liddell, R. Scott, A Greek-English Lexicon, Oxford 1996, s. 1308-1309.

${ }^{6}$ Zob. G. Colli, Narodziny filozofii, tłum. S. Kasprzysiak, Warszawa-Kraków 1991, s. 52. 
tym samym wyzwanie, któremu może sprostać tylko inny mędrzec ${ }^{7}$. Zadaniem tego ostatniego staje się przedarcie przez absurd i dotarcie do kryjącego się za nim racjonalnego jądra. Jeśli tego dokona, sam zasłuży na miano mędrca, zagadka bowiem stanowi bramę do tego, co tajemnicze, ukryte i boskie ${ }^{8}$. Owe starogreckie zagadki-paradoksy, takie jak ta, która miała się stać przyczyną śmierci Homera ${ }^{9}$, w toku rozwoju kultury helleńskiej wyewoluowały w dwóch kierunkach: z jednej strony paradoks stał się instrumentem wyrażania treści filozoficznych, a z drugiej włączony został do instrumentarium rodzącej się w $\mathrm{V}$ wieku p.n.e. sztuki retorycznej. Na rozdrożach tego procesu przemian stoją przedstawiciele pierwszej sofistyki, dla których paradoks był zarówno metodą wyrażania treści filozoficznej, jak i narzędziem perswazji, które pozwala przykuć uwagę audytorium. Do paradoksów trzeba zaliczyć zarówno twierdzenie Protagorasa, zgodnie z którym „Człowiek jest miarą wszystkich rzeczy: istniejących, że istnieją, nieistniejących, że nie istnieją", jak i Gorgiaszową naukę o tym, że nic nie istnieje, niczego nie da się poznać i niczego nie da się nikomu przekazać. Oba te twierdzenia spełniały zarówno funkcje retoryczne - miały przykuwać uwagę słuchaczy i rodzić napięcie, które mówca w swojej mowie popisowej mógł rozładowywać — jak i stanowiły bramę do zrozumienia treści filozoficznej, którą był radykalny relatywizm epistemologiczny i ontologiczny.

Myślicielem, za sprawą którego dokonała się ostateczna retoryzacja paradoksu, był Arystoteles. On wskazał na byt jako przedmiot dociekań filozoficznych ${ }^{10}$, zaś fundamentem swoich badań filozoficznych uczynił zasadę sprzeczności, co w konsekwencji musiało prowadzić do wniosku, że paradoks jako narzędzie przekonywania musi być pomieszczony w sferze tego, co jest jedynie mniemaniem, natomiast za sztukę, która naucza zasad urabiania mniemań, musiała być uznana retoryka ${ }^{11}$. Paradoks zostaje przez niego umieszczony w kategorii maksym wymagających uzupełnienia i staje się jednym z wielu środków przekonywania ${ }^{12}$.

W rozważaniach Arystotelesa nad paradoksem jako środkiem perswazji retorycznej znajdujemy pewien moment, który może stanowić dogodny punkt wyjścia dla bliższego określenia roli, jaką w cynicznym sposobie mówienia odgrywają twierdzenia, które określam mianem paradoksów cynicznych. Oto przy okazji omawiania toposów retorycznych, dzięki którym można zmusić przeciwnika w dyskusji do przyjęcia poglądów trudnych do uzasadnienia, Arystoteles stwierdza:

${ }^{7}$ R.P. Martin, The Seven Sages as Performers of Wisdom, [w:] Cultural Poetics in Archaic Greece: Cult, Performance, Politics, C. Dougherty, L. Kurke (eds.), New York-Oxford 1998, s. 119-120.

8 Zob. ibidem, s. 56-58.

${ }^{9}$ Homer ostrzeżony przez wyrocznię Delficką, aby wystrzegał się zagadki zadanej przez dzieci, po powrocie na rodzinne Ios spotkał wracających z nieudanego połowu młodych rybaków, którzy zapytani przez poetę o to, czy mieli udany połów, odpowiedzieli: „Cośmy złowili, tośmy wyrzucili, a czegoś my nie złowili, to wieziemy ze sobą", mając na myśli wszy, których iskaniem byli zajęci (zob. D.B. Levine, Poetic Justice: Homer's Death in the Ancient Biographical Tradition, „The Classical Journal” 98 (2002/2003), s. 141-142).

${ }_{10}$ Arystoteles, Metafizyka, tłum. K. Leśniak, Warszawa 1984, 1003a, s. 71.

${ }^{11}$ M.J. Hyde, op. cit., s. 208.

12 Ibidem, s. 201. 
Najmocniejszym miejscem do wywołania paradoksalnych twierdzeń jest to, według którego i Kallikles dowodzi w Platońskim Gorgiaszu, i według którego także i dawniejsi sofiści usiłowali na tej drodze swój cel osiągnąć, jest rozróżnienie: „wedle natury” i „według prawa”; bo natura [tak twierdzą] i prawo są przeciwieństwami; i sprawiedliwość według prawa jest piękna, a według natury nie jest piękna. Należy więc tego, który się opowiada za naturalnym punktem widzenia skojarzyć z punktem widzenia „,według prawa", a tego, który się opowiada za prawem, skierować do faktów przyrody; w obydwu bowiem przypadkach powstaną paradoksalne twierdzenia. Według ich poglądu miernik przyrody był prawdziwy, podczas gdy miernik prawa wydawał się prawdziwym większości. Okazuje się więc, że zarówno tamci sofiści, jak i dzisiejsi usiłują albo odeprzeć argumentację odpowiadającego, albo zmusić go do wygłaszania twierdzeń paradoksalnych ${ }^{13}$.

Dalej określa on szczegółowo strategię, jaką należy się posłużyć przy wykorzystaniu tego toposu:

Niektóre pytania tak są sformułowane, że odpowiedź w każdym przypadku jest paradoksalna, jak na przykład: „Czy należy słuchać mędrców, czy ojca?” albo: „Czy należy działać korzystnie, czy sprawiedliwie?” albo: „Czy lepiej czynić zło, czy je znosić?”. Trzeba więc skierować przeciwnika bądź do tego, co się sprzeciwia poglądom większości, bądź do tego, co się sprzeciwia poglądom filozofów, a mianowicie do przeciwieństwa poglądów większości, gdy przeciwnik głosi pogląd filozofów, a do przeciwieństwa poglądów filozofów, gdy głosi pogląd większości ${ }^{14}$.

Stagiryta odnosi się tutaj rzecz jasna do słynnego sporu, jaki na kartach Gorgiasza toczą z sobą Kallikes i Sokrates. Trzeba jednak zauważyć, że Kallikles w swojej strategii argumentacyjnej postępuje w sposób zgoła przeciwny do tego, jaki zaleca Arystoteles. Nie stara się wcale zmusić Sokratesa do wypowiedzenia paradoksalnego sądu, zgodnie z którym lepiej jest zła doznawać, niż je wyrządzać. Przeciwnie: to sam Sokrates wypowiada owo trudne do obrony twierdzenie we wcześniejszej rozmowie z Polosem ${ }^{15}$. Twierdzenie to jest zatem dla Kalliklesa punktem wyjścia, a nie dojścia strategii argumentacyjnej. Sofista wcale nie zmusza Sokratesa do zajęcia wyrażonego w paradoksie stanowiska, za to sam głosi, jak pokażę, poglądy niezgodne ani z poglądem większości, ani z poglądem filozofów, przez co jego mowa wydaje się czytelnikowi, jeśli można tak powiedzieć, paradoksalna w dwójnasób. Warto zauważyć, że sam Kallikles jasno formułuje pod adresem Sokratesa zarzut posługiwania się sofizmatem opisanym przez Arystotelesa. Stwierdza on mianowicie:

Ty, istotnie, Sokratesie, lubisz ciągnąć do takich ciężkich i dobrych dla tłumu efektów, mówiąc, że prawdy szukasz, efektów, które z natury nie są piękne, tylko wedle prawa opinii. A w większości wypadków to jest jedno drugiemu przeciwne: natura z jednej strony, a prawo opinii z drugiej. Więc, jeżeli się ktoś wstydzi i nie śmie powiedzieć, co myśli, to musi mówić rzeczy, z których jedna się drugiej sprzeciwia. Tyś ten sekret zauważył i teraz sobie używasz w rozmowach; jeżeli ktoś mówi wedle prawa, ty mu podsuwasz sens wedle natury, a jeśli on wedle natury, to ty wedle praw ${ }^{16}$.

Sofista nie zagania swojego przeciwnika w kozi róg, w którym ten musiałby wypowiadać zdania brzmiące niewiarygodnie w uszach ludu albo w uszach mędrców,

${ }^{13}$ Arystoteles, O dowodach sofistycznych, [w:] idem, Topiki. O dowodach sofistycznych, tłum. K. Leśniak, Warszawa 1978, 173a 270.

14 Ibidem, s. 270-271.

15 Platon, Gorgiasz, [w:] idem, Dialogi, tłum. W. Witwicki, t. 1, Kęty 1999, 269b-c, s. 372.

16 Ibidem, 482e-483a, s. 393. 
ale sam ochoczo wypowiada zdania, które muszą się wydawać paradoksalne dla obu audytoriów. Oto przykład Kalliklesowego paradoksu:

jeśli się ktoś szczęśliwym trafem urodził synem królewskim, albo miał zdolności i dorwał się do takiego berła czy tronu tyrana, czy autokraty, to cóż by u takiego człowieka mogło być bardziej hańbiące i brzydsze niż rozsądek i sprawiedliwość? ${ }^{17}$

Pogląd wygłoszony przez Kalliklesa stanowi przykład tego właśnie rodzaju paradoksu, który określam mianem paradoksu cynicznego. Tym, co wyróżnia ten rodzaj paradoksu, jest to, że szok i zdziwienie, jaki wywołuje on u słuchaczy, pojawiają się jako reakcja na niezgodność wypowiadanego poglądu z szeroko akceptowanymi intuicjami moralnymi. Platoński Kallikles, wypowiadając te słowa, zdaje sobie z pewnością sprawę, jaki efekt muszą one wywrzeć na słuchaczach, których wychowano w czci dla roztropności i sprawiedliwości. Oto rozsądek i sprawiedliwość okazują się w pewnych okolicznościach czymś brzydkim i hańbiącym. Szczególna moc tego paradoksu bierze się z takiego właśnie złączenia w jednym zdaniu czterech określeń, z których dwa pierwsze: „hańba ciø $\chi$ เov” i „brzydota xáxı๐" dla ucha greckiego musiały brzmieć jak najwyższy rodzaj nagany, a dwa

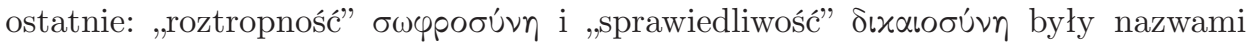
najwyżej cenionych cnót, jakimi człowiek może w ogóle się przyozdobić. To, co godne podziwu zostało uznane za godne pogardy. Poczucie paradoksalności rodzi się w tym przypadku, a jest to pierwsza z cech paradoksów, które określam mianem paradoksów cynicznych, ze swego rodzaju semantycznego wstrząsu, jakiego doznaje słuchacz przyzwyczajony widzieć w cnotach rzeczy godne pochwały, gdy tymczasem Kallikles odrzuca je i potępia jako złe i hańbiące.

Podobnym do Kalliklesowego paradoksem posłużył się inny sofista z dialogów Platona Trazymach, który w pierwszej księdze Państwa formułuje niesławną definicję sprawiedliwości, zgodnie z którą, „to, co sprawiedliwe, to nic innego, jak tylko to, co leży w interesie mocniejszego"18. W tym przypadku mówca cyniczny nie określa wprost cnoty sprawiedliwości mianem wady, ale przyciśnięty przez Sokratesa przyznaje, że uważa sprawiedliwość za cechę, która może zostać uznana w najlepszym przypadku za rodzaj szlachetnej naiwności, będącej w gruncie rzeczy wadą ${ }^{19}$. Wystąpienie Trazymacha wprawia rozmawiajacych w zakłopotanie, bo o ile próbowali oni odpowiedzieć na pytanie o naturę sprawiedliwości w mniemaniu, że sprawiedliwość jest bez wątpienia czymś dobrym, o tyle teraz założenie to podano w wątpliwość i zanim będą mogli wrócić do poprzednich rozważań, najpierw będą musieli uzasadnić samo to sproblematyzowane w toku rozmowy

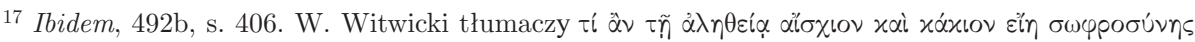

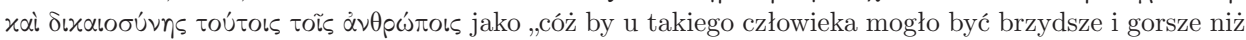
panowanie nad sobą”, jednak tłumaczenie bardziej dosłowne, które proponuję („,óż by u takiego człowieka mogło być bardziej haniebne i brzydsze niż rozsądek i sprawiedliwość"), wydaje się bliższe sensowi oryginału i lepiej oddaje paradoksalny charakter poglądu Kaliklesa, nie stwarzając jednocześnie pozoru, że mowa jest w nim o Sokratejskiej enkratei, które to pojęcie nie było, jak się wydaje, na tyle zakorzenione w mowie potocznej, aby wywołać u pierwszych czytelników Gorgiasza to poczucie paradoksalności, jaki wywołuje u nas, którzy zostaliśmy wychowani w duchu Zachodniego moralizmu.

18 Platon, Państwo, tłum. W. Witwicki, Warszawa 2010, 338c, s. 37.

19 Ibidem, 348d-e, s. 52. 
Sokratesa z Trazymachem milczące założenie, zgodnie z którym sprawiedliwość jest czymś dobrym i godnym polecenia. W drugiej księdze Państwa Adejmant stwierdza wprost:

Tyle, Sokratesie, a może i więcej jeszcze mógłby Trazymach, albo może i ktoś inny też, powiedzieć o sprawiedliwości i niesprawiedliwości, ale to by było odwracanie ich właściwej mocy w sposób gruby, jak uważam ${ }^{20}$.

W gruncie rzeczy cały wysiłek, jaki wkładają rozmawiający w rozważania nad prawdziwą naturą sprawiedliwości, można uznać za próbę obrony sprawiedliwości przed potępieniem, które spotkało ją ze strony Trazymacha ${ }^{21}$. Oskarżenie to, jak ujmuje Adejmant, odwróciło właściwą jej moc, podobnie jak paradoks cyniczny Kalliklesa odwrócił właściwą moc rozsądku i sprawiedliwości. Mechanizm owego odwrócenia mocy w przypadku definicji sprawiedliwości sformułowanej przez Trazymacha można za Charlesem Stevensonem określić mianem quasi-definicji perswazyjnej. Zabieg ten polega na zmianie emotywnego znaczenia słów, które potocznie używane są do wydawania sądów wartościujących. Termin posiadajacy wyraźne znaczenie emotywne zostaje zdefiniowany w taki sposób, że dla słuchaczy musi stać się wątpliwe, czy powinni oni wiązać z nim owo znaczenie i czy nie słuszniej byłoby owo znaczenie odwrócić. Rozważania Stevensonowskie prowadzone są w kontekście analizowanego przez niego pojęcia definicji perswazyjnej, stanowiącego jego zdaniem jedno z podstawowych narzędzi argumentacji moralnej, ale choć przykład twierdzenia Trazymacha ma wyraźnie formę definicji równościowej, amerykański myśliciel określa je mianem quasi-definicji perswazyjnej. Swój wybór terminologiczny uzasadnia w następujący sposób:

Cases of this sort do not exemplify persuasive definitions, in spite of their similar function. They involve a linguistic change which is mediated not by definitions, but rather by gestures, tones of voice, or rhetorical devices such as similes and metaphors. It is convenient to restrict the term "definition" to cases where descriptive meaning alone is being determined, or where, at least, that aspect predominates. Thus the above example involves no definition, but only what may be called (for temporary brevity, and in want of a better term) a persuasive quasi-definition ${ }^{22}$.

Przytoczone słowa Kalliklesa z Platońskiego Gorgiasza, w którym rozsądek i sprawiedliwość uznaje się za cechy brzydkie i hańbiące, spełniają bardzo podobną funkcję perswazyjną. W kontekście narracyjnym nie sposób sobie wyobrazić, że Kallikles wypowiada te słowa z myślą o poczynieniu ostrożnych rozróżnień pojęciowych. Czytelnik dialogu przedstawia sobie scenę dialogu raczej jako zażarty spór między przeciwnikami, którzy mają nie tylko odmienne poglądy, lecz także cele perswazyjne.

${ }^{20}$ Ibidem, 367b-d, s. 78 .

${ }^{21}$ Ch.L. Stevenson, Definicje perswazyjne, tłum. M. Pietrzak, „Studia z Historii Filozofii” 2 (2015), s. $33-34$.

22 „Zabiegi tego typu nie są przykładami definicji perswazyjnych, mimo, że pełnią podobną do nich funkcję. W ich przypadku w grę wchodzi zmiana językowa, która nie dokonuje się za pomocą definicji, ale raczej gestu, tonu głosu czy takich zabiegów retorycznych, jak porównanie czy metafora. Słusznym będzie zastrzeżenie terminu »definicja« do przypadków, w których, w których jedynie treść pojęciowa ulega modyfikacji, albo takich, w których ten aspekt dominuje. W tym przypadku nie mamy zatem do czynienia z definicją, ale raczej z czymś, co można określić (tymczasowo i z braku lepszego określenia) mianem quasi-definicji perswazyjnej" (Ch.L. Stevenson, Ethics and Language, New Haven 1944, s. 278). 
Strategię Sokratesa można określić mianem moralistycznej. Jej celem jest narzucenie rozmówcom nowego rozumienia terminów języka moralności, bez zmiany ich znaczenia emotywnego. Doznawanie zła i jego wyrządzanie pozostają przy tym rozumieniu nadal rzeczami godnymi odrzucenia, ale zmieniona, a może tylko uporządkowana zostaje hierarchia tych określeń: wyrządzanie krzywd staje się czymś w wyższym stopniu odpychającym niż ich doznawanie. Strategia Kalliklesa ma na celu udaremnienie zabiegów Sokratesa przez odwrócenie znaczeń emotywnych, jakie przydaje on słowom języka moralności. Oto teraz to, co roztropne i sprawiedliwe okazuje się czymś godnym pogardy i hańbiącym. Przy takim rozumieniu znaczenia tych pojęć wszelkie próby moralizowania i porządkowania sfery moralnej muszą być z konieczności uznane za pozbawione sensu. Strategia Kalliklesa wydaje się próbą udaremnienia zabiegów Sokratesa. Można ją określić mianem kontrstrategii — sofista nie stara się na serio bronić swoich poglądów, ale raczej podejmuje próbę neutralizacji argumentacji moralisty poprzez zanegowanie jej, jeśli można się tak wyrazić, emotywnych założeń. Te dwie strategie w kontekście toczącego się sporu moga być określone mianem strategii moralisty i strategii immoralisty. Ten reaktywny charakter argumentacji Kalliklesa dostrzega Platoński Sokrates, kiedy wyraźnie ironicznie wychwala Kalliklesa jako przeciwnika szczerego i życzliwego:

Bo myślę sobie - mówi Sokrates - że kto ma być dobrym probierzem na to, czy jakaś dusza słusznie żyje, czy nie, ten musi posiadać trzy przymioty, które ty w sobie łączysz: wiedzę, życzliwość

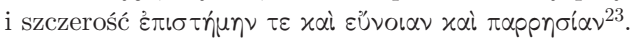

Problem nieszczerości zostaje podniesiony wprost również w rozmowie Sokratesa z Trazymachem:

- [... nie trzeba się wzdrygać przed prześledzeniem i tego stanowiska z uwagą, jak długo przypuszczam, że mówisz to, co myślisz. Ja mam wrażenie, Trazymachu, że ty teraz nie kpisz sobie po prostu, tylko mówisz to, co ci się wydaje o prawdzie.

- A co ci na tym zależy — powiada - czy mnie się tak wydaje, czy nie; czemu nie zbijasz samego stanowiska $^{24}$ ?

Trazymach wyraźnie odmawia zadeklarowania, czy poglądy, które wygłasza, zgodne są z jego przekonaniem, czy też są jedynie paradoksami mającymi za zadanie skonfundować audytorium. Nieco wcześniej Sokrates wzywał swojego przeciwnika, aby odpowiadając na pytania, nie mówił rzeczy niezgodnych z własnym

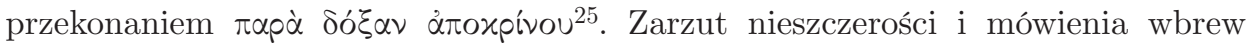
własnemu przekonaniu wskazuje moim zdaniem na reaktywny charakter sądów przybierających formę omawianych tutaj paradoksów. Ci, którzy je wygłaszają, nie starają się na serio bronić ich prawdziwości, ale swoje wysiłki kierują na udaremnienie strategii argumentacyjnej przeciwnika, która najczęściej przybiera formę strategii moralistycznej, to znaczy takiej, która ma modyfikować znaczenia wyrażeń wchodzących w skład języka moralności. Strategia perswazyjna, jaką posługują się zarówno Trazymach, Kallikles, jak i ich późniejsi naśladowcy zasługuje w związku z tym na miano strategii immoralistycznej, zaś postawa

\footnotetext{
${ }^{23}$ Platon, Gorgiasz, 487a, s. 398.

${ }^{24}$ Platon, Państwo, 349a, s. 49.

${ }^{25}$ Ibidem, 346a.
} 
przyjmowana przez cynicznego mówcę może być określona mianem immoralizmu cynicznego.

Opisana relacja między strategią moralizującą a kontrstrategią immoralisty stanowi właściwy kontekst, w którym wygłaszane są paradoksy podobne do tych, których przykłady podałem wyżej, a które chcę określić mianem paradoksów cynicznych. Ich sens jest zatem określony przez użytek, jaki można z nich uczynić w kontekście sporu toczonego przez mówcę z kimś, kto posługuje się strategią mającą na celu modyfikację treści pojęciowych wyrażeń języka moralności, aby $\mathrm{w}$ ten sposób dokonać zmiany w preferencjach moralnych audytorium bez zmieniania sensu emotywnego owych wyrażeń. Podmiot wypowiadający paradoksy cyniczne i posługujący się wskazaną kontrstrategią będę określać mianem mówcy cynicznego, samą zaś strategię mianem kontrstrategii cynicznej. Pojęcia te wprowadzam dla uniknięcia w dalszych rozważaniach zbyt szerokich omówień, które mogłyby uczynić mój wywód niezrozumiałym. Posługując się tymi pojęciami, moge przystąpić do dalszych rozważań dotyczących modus operandi mowy cynicznej.

\section{Modulacja cyniczna}

Uznając zasadniczą słuszność poglądu sformułowanego przez Kennetha Burke’a, zgodnie z którym celem aktu retorycznego jest uzyskanie retorycznej konsubstancjacji mówcy z audytorium ${ }^{26}$, spróbuję pokazać, w jaki sposób operujący paradoksami mówca cyniczny stara się zarządzać tożsamościami słuchaczy i skłonić ich do przejścia na swoją stronę w dyskusji. Mówiąc o tożsamości audytorium, która jest przedmiotem zabiegów retorycznych, trzeba pamiętać, że nie ma ona charakteru bezwzględnego, ale jest raczej systemem odniesień, których siatka określa stan świadomości podmiotów w obrębie danej społeczności:

Tak zwane ,ja” - pisze K. Burke - jest po prostu unikalną kombinacją różnych, częściowo skonfliktowanych „wspólnotowych my” [...]. Czasem poszczególne tożsamości współgrają zgodnie. Innym razem popadają w konflikty mające ponure konsekwencje moralne ${ }^{27}$.

Członkowie audytorium identyfikują siebie samych przy pomocy takich określeń, jak: „Polak”, „ojciec”, „dziecko”, „uczeń”, „biznesmen”, „siostra”, „przyjaciel” itp., które współtworzą treść tego, co można określić mianem ich tożsamości. Sama natura tych określeń sprawia, że owa tożsamość zawsze musi być odniesiona do innych tożsamości i tworzyć wraz z nimi pewien układ, którego zrozumienie jest pierwszym krokiem do przeprowadzenia udanego zabiegu retorycznego. W akcie tym mówca stara się zarządzać owymi identyfikacjami i dokonać zamierzonej przez siebie ich rekonfiguracji, przywołując jedne, a spychając w cień inne. Jeśli jednak celem aktu retorycznego jest, jak sądzi Burke, konsubstancjacja mówiącego ze słuchającymi, to można ją osiągnąć na dwa sposoby.

\footnotetext{
${ }^{26}$ K. Burke, Rhetoric of Motives, Los Angeles-Berkeley 1969, s. 22.

${ }^{27}$ K. Burke, Attitudes toward History, Berkeley 1984, s. 264.
} 
Pierwszy z nich to utożsamienie się wprost z członkami audytorium przez autoprezentację, która pokaże mówcę jako kogoś, kto przynależy do audytorium i podziela jego zbiorowe tożsamości. Jest to droga bardziej uczęszczana i nią idzie na przykład szekspirowski Brutus, gdy rozpoczyna swoją słynną mowę od słów: „Wysłuchajcie mnie cierpliwie do końca. Rzymianie — rodacy i przyjaciele!”28. Ten sposób przekonywania jest mocno osadzony w tradycji retorycznej, a to ze względu na pochodzenie owej sztuki, która zrodziła się w ramach ustanowionych przez dyskurs demokratyczny, w obrębie którego obie strony aktu retorycznego trzeba uznawać za równe sobie i podzielające to same zbiorowe „my”. Drugi sposób polega na wpleceniu relacji między mówiącym i słuchającymi w sieć opozycji, w jakich znajdują się wobec siebie wspomniane wspólnotowe tożsamości. W tym przypad$\mathrm{ku}$ obu stronom aktu retorycznego zostają przydane odmienne, acz powiązane z sobą identyfikacje. Dzieje się tak na przykład wtedy, gdy retor, ustanawiając swój autorytet jako osoby doświadczonej i roztropnej, stawia się w pozycji doradcy lub nauczyciela albo gdy jako surowy sędzia złorzeczy publiczności. Ten sposób budowania więzi między mówiącym a słuchającymi może się pojawić w mowach doradczych, kiedy to mówca w sposób autorytatywny, wspierając się na właściwej dla danej sprawy formie ethosu, przedstawia publiczności odpowiedni jego zdaniem sposób postępowania i stara się ją odwieść od postępków i przekonań, które uznaje za niewłaściwe i błędne. Może mieć on również zastosowanie w kontekście oskarżeń rzucanych pod adresem publiczności, kiedy to mowa przybiera formę zbliżoną do kazania. Ten ostatni sposób przemawiania możemy odnaleźć w Platońskiej Obronie Sokratesa, kiedy to skazany na śmierć filozof odwraca poniekąd ustanowioną przez kontekst mowy relację między sobą a swoimi sędziami, sam przyjmując ton oskarżycielski i osądzający wobec tych, którzy dopiero co skazali go na śmierć. Przyjmuje on przy tym pozę proroka, budując swój autorytet, odwołując się niejako do sfery tego, co boskie:

A teraz pragnąłbym wam coś przepowiedzieć, wy, którzyście mnie skazali. Jestem przecież u tego kresu, przy którym ludzie najwięcej wieszczyć zwykli: kiedy mają umrzeć. Przepowiadam wam więc, obywatele, którzyście mnie zabili, że przyjdzie na was kara zaraz po mojej śmierci, znacznie cięższa, na Zeusa, niż ta, którą mnie zabijacie. Bo wyście to dziś popełnili, myśląc, że się pozbędziecie ciągłego rachunku sumienia w życiu; tymczasem wypadnie wam coś całkiem przeciwnego. Powiadam wam. Więcej się znajdzie takich, którzy was oskarżać będą; ci, których ja teraz byłem natchnieniem, a wyście tego nie widzieli. Będą tym przykrzejsi, im są młodsi: toteż was będą znacznie więcej oburzali ${ }^{29}$.

Mówca cyniczny ustanawia relację między sobą a publicznością właśnie na ten drugi sposób. Stawia on siebie poza audytorium i przyjmuje postawę nauczyciela, który nie pospolitując się w relacjach ze swoimi rozmówcami i słuchaczami, zwraca się do nich z pozycji reprezentanta pewnego rodzaju sztuki i powiązanego z owa sztuką ethosu. Kluczowe dla zrozumienia modus operandi mowy cynicznej jest ukazanie, w jaki sposób mówiący ustanawia relację między sobą a publicznością i w jaki sposób następnie ową relacją zarządza.

\footnotetext{
${ }^{28}$ W. Shakespeare, Juliusz Cezar, tłum. S. Barańczak, Poznań 1993, s. 85.

${ }^{29}$ Platon, Obrona Sokratesa, 39 b-d, s. 579.
} 
Pierwszym krokiem na drodze do zbudowania pożądanej przez cynicznego mówcę relacji z publicznością jest przypisanie publiczności takiej tożsamości, która będąc nieatrakcyjną, nie może być przez nią zaakceptowana. W przypadku Trazymacha sprawa przedstawia się bardzo klarownie. Zanim przystąpi on do wygłaszania mowy potępiającej sprawiedliwość, zaczyna w napastliwy sposób atakować swoją publiczność jako ludzi naiwnych i zakłamanych, którzy wolą schlebiać sobie nawzajem, niż spojrzeć na rzecz samą chłodnym okiem. Chwilę, w której sofista włącza się do rozmowy, opisuje Platon ustami Sokratesa:

Otóż Trazymach często już, kiedyśmy rozmawiali, chciał nam przerywać i rwał się do głosu, ale mu przeszkadzali siedzący obok i chcący rzeczy dosłuchać do końca. Więc kiedyśmy zrobili pauzę i ja ostatnie słowa powiedziałem, już nie mógł dalej wytrzymać, tylko się skupił w sobie jak zwierz i rzucił się na nas, jak by nas chciał rozszarpać. Więc na mnie i na Polemarcha padł strach jak na spłoszone ptaki, a on przy wszystkich na cały głos powiada: - Co to za brednie was się tutaj trzymają już od dawna, Sokratesie? I czemu to z was jeden po drugim udaje głupiego i jeden drugiemu ustępuje miejsca ${ }^{30}$ ?

Gdy już przydana została publiczności zbiorowa tożsamość grupy schlebiających sobie naiwniaków, mówca cyniczny przystępuje do budowania własnej tożsamości, która opierać się będzie na charakterystycznym dla sofistów obrazie fachowca czy też mędrca oọós, którym to mianem określa go sam Sokrates (337a). Aby podkreślić fachowy czy też ekspercki charakter swoich wywodów, Trazymach żąda zapłaty za udzielenie odpowiedzi na postawione przez Sokratesa pytanie o naturę sprawiedliwości:

- A co wtedy - powiada - jeżeli ja wskażę i inną odpowiedź, różną od tych wszystkich, na temat sprawiedliwości, i to lepszą od tych? Co będzie z tobą, jak sądzisz?

- Cóż innego - mówię - jak nie to, co musi być z tym, który nie wie. Wypada, żeby się nauczył od tego, co wie. Więc ja myślę, że właśnie to będzie i ze mną; i dobrze.

- Bo ty jesteś sympatyczny - powiada. - Ale oprócz tego, że się nauczysz, zapłacisz jeszcze i gotówkę.

- Nieprawdaż — jak będę kiedyś miał — mówię.

- Ależ masz już pieniądze — zawołał Glaukon. — Jeżeli chodzi o pieniądze, Trazymachu, to mów. My wszyscy złożymy się dla Sokratesa ${ }^{31}$.

W ten sposób Trazymach jako mówca cyniczny ustanawia wyjściową relację między sobą jako fachowcem czy też ekspertem a swoimi słuchaczami jako dyletantami, których musi pouczyć co do prawdziwej natury przedmiotu ich rozmowy. Trzeba zauważyć, że punkt wyjścia obrany przez sofistę z punktu widzenia celu aktu retorycznego, którym ma być konsubstancjacja mówcy z audytorium, może się wydawać dysfunkcjonalny. Oto zamiast zbliżyć obie strony owego aktu, przeciwstawia je sobie, wynosząc mówcę na poziom niedostępny dla słuchających, a czyni to dodatkowo otwarcie wyrażaną pogardą dla ich naiwności. Aby zrozumieć perswazyjny sens tego zabiegu, trzeba przyjrzeć się sposobowi, w jaki Trazymach uzasadnia wygłoszony przez siebie paradoks i w jaki sposób będzie bronił swojego poglądu. W swoim uzasadnieniu wychodzi on od prostej obserwacji, że w każdym państwie prawa ustanawiają ci, którzy mają najwięcej siły. W monarchii najmocniejszy jest król i on ustanawia prawa, które będą służyć jego interesom. Podobnie

\footnotetext{
${ }^{30}$ Platon, Państwo, 336a-b, s. 34.

31 Ibidem, $337 \mathrm{~d}-\mathrm{e}$, s. 36.
} 
w arystokracji prawa służą członkom rządzącej elity. W demokracji w końcu prawa służą ludowi, który ustanawiając prawa, jawnie okazuje swoją dominującą pozycję $^{32}$. Sokrates stara się podważyć argument Trazymacha, stwierdzając, że politycy ustanawiajacy prawa podobni są do pasterzy, którzy dbają o dobro swojego stada, i do lekarzy, których celem jest nie swoja pomyślność, ale dobro powierzonych ich pieczy pacjentów ${ }^{33}$. Jest to kluczowy moment w dyskusji, Sokratesowy kontrargument i wyrażona w nim postawa pozwala Trazymachowi na przeprowadzenie swojego wywodu do końca. Naiwny moralizm, z jakim Sokrates wypowiada swoje słowa o lekarzach i pasterzach dbajaccych jedynie o dobro tych, którzy powierzeni zostali ich pieczy, staje się dogodnym punktem odniesienia dla mówcy cynicznego, który może ponownie przed oczami publiczności skontrastować dobroduszną naiwność swojego przeciwnika z własnym chłodnym osądem spraw i ludzi. Mówi on:

Bo tobie się zdaje, że pasterze owiec i krów mają na oku dobro owiec i krów i tuczą je, i chodzą koło nich, mając na oku coś innego niż dobro swoich panów i własne, i tak samo ci, co rządzą w państwach, którzy naprawdę rządzą, myślisz, że jakoś inaczej się odnoszą do rządzonych niż jak do owiec i o czymś innym myślą nocą i dniem, jak nie o tym, skąd by wyciągnać jak największą korzyść dla siebie ${ }^{34}$.

Ton i sens wypowiedzi Trazymacha jest znamienny. Rządzaccy dbają tylko o własną korzyść, a do poddanych odnoszą się tak jak pasterze do swoich owiec, a więc zamyślają tylko o tym, jak by ich, jeśli wolno w oczywisty sposób rozwinąć metaforę, wydoić, ostrzyc albo zaprowadzić do rzeźni. Mowa Trazymacha staje się tutaj prawdziwie cyniczna, choć w owym cynizmie pobrzmiewa też coś w rodzaju gorzkiego morału. Słuchacze muszą teraz wybrać między optymistycznym obrazem polityki przedstawionym przez Sokratesa a realistycznym, a może nawet hiperrealistycznym poglądem Trazymacha. Ponieważ jednak wcześniej mówca cyniczny zbudował relację między samym sobą a nimi w taki sposób, że przeciwstawił ich naiwność swojej fachowości, przed członkami audytorium stoi teraz wybór: albo pozostaną naiwnymi moralistami, albo staną po stronie trzeźwo myślącego i nieulegającego złudzeniom realisty. Jeśli wybiorą tę drugą drogę, będą mogli się uwolnić od nieatrakcyjnej tożsamości naiwnych dyletantów i staną się uczniami cynicznego mistrza w fachu i przez samo to poczują się poniekąd wtajemniczeni w arkana sztuki praktycznego radzenia sobie w życiu. Trazymach mówi o rządzących w sposób pozbawiony emocji, chłodny i rzeczowy. Ujawnia cynicznie prawdziwy obraz rzeczywistości politycznej, nie zwracając uwagi na niechęć, jaką może on wzbudzić u tych, którzy nie potrafią się uwolnić od poprawiajacych samopoczucie złudzeń co do sposobu, w jaki „toczy się światek”. Trazymach wydaje się postępować $\mathrm{w}$ sposób przeciwny do tego, jaki jest charakterystyczny dla mówcy publicznego. Ten ostatni, mówiąc o polityce, stara się ją przedstawić ubraną w szaty wzniosłych ideałów i troski o dobro publiczne. Sofista tymczasem odziera politykę z wszelkich ozdób i ukazuje ją jako twardą walkę o własny interes, w której liczą się nie ideały i sentymenty, lecz siła.

\footnotetext{
32 Ibidem, 338d-339a, s. 37-38.

33 Ibidem, 342d, s. 44.

${ }^{34}$ Ibidem, 343a-b, s. 45.
} 
Ten rodzaj komunikacji opisał Ervin Goffman, który określa go mianem komunikacji zakulisowej. Zejście ze sceny, na której następuje zetknięcie społecznego aktora i publiczności, wiąże się z wejściem w nowy rodzaj interakcji powstającej między tymi, którzy są odpowiedzialni za stwarzanie pozorów składających, z których utkane są wydarzenia przedstawiane na scenie. Aktorzy posługują się tutaj językiem szorstkim i kpią z publiczności. Powodzenie przedstawienia zależy poniekąd od tego, żeby kulisy były miejscem ukrytym przed publicznością, do którego jej członkowie nie mają dostępu ${ }^{35}$ :

Kulisy czy też garderoba - pisze E. Goffman — to miejsca, gdzie najzupełniej świadomie przeczy się ważeniom, których wywołaniu służy przedstawienie. Pełnią one oczywiście liczne funkcje, znamienne dla takich miejsc. Tutaj pracowicie można fabrykować te fragmenty przedstawienia, które pozwalają mu wyrażać coś poza samym sobą, tutaj jawnie produkuje się złudzenia i pozory ${ }^{36}$.

Wejść za kulisy to przejść od świata pozorów do rzeczywistości, w której owe pozory są pracowicie budowane. Ten, kto zostanie dopuszczony do oglądania kulis, może czuć się wtajemniczony i rozczarowany jednocześnie. Efekt, jaki mowa Trazymacha wywiera na jego słuchaczach, można przyrównać właśnie do wejścia za kulisy. Świat polityki, który może się jawić naiwnym obserwatorom jako miejsce, w którym dba się o dobro obywateli i pracowicie krząta wokół dobra wspólnego, jawi się teraz jako plac boju, w którym różne frakcje walczą o to, kto będzie miał możliwość grabienia i wykorzystywania do własnych celów poddanej hipnotycznemu urokowi ideologicznej złudy naiwnej publiczności. Rzeczowy chłód charakteryzujący mowę Trazymacha stwarza sugestię, że oto zostaliśmy dopuszczeni za kulisy. Nie jesteśmy już naiwnymi widzami, którzy z otwartymi ustami oglądają rozsnuwane przed nami pozory, ale stajemy po stronie twórców przedstawienia. Tak cyniczny mówca w niedostrzegalny sposób przekształca wyjściową relację między sobą jako fachowcem a publicznością jako grupą naiwnych dyletantów. Dopuszczenie publiczności do tajników pracowicie ukrywanych za kulisami polityki oznacza zaoferowanie jej nowej, znacznie atrakcyjniejszej tożsamości uczniów cynicznego mistrza. Jako uczniowie mistrza mogą oni odrzucić tożsamość dyletantów i stać się członkami cechu, dopuszczonymi do oglądania tego, co przed publicznością pozostaje ukryte. W ten sposób cyniczny mówca pozwala publiczności przejść na swoją stronę. Publiczność sama staje się cyniczna i w ten sposób dokonuje się retoryczna konsubstancjacja między mówcą cynicznym i jego audytorium. Zabieg ten określam mianem m o d u l a c j i c y n i c z n e j. W toku tej modulacji mówca dokonuje zmiany w obrębie skonstruowanych na zasadzie binarnych opozycji tożsamości własnej i audytorium. Relacja fachowiec-dyletanci zmienia się w relację mistrz-uczniowie, co uwalnia publiczność od dyskomfortu.

Zabieg ten można opisać przy użyciu aparatu pojęciowego analizy transakcyjnej jako zabieg przeciwprzeniesienia, w którym mówca cyniczny wchodzi z publicznością w relację określona przez Erica Berne’a jako transakcja skrzyżowana typu II, czyli taka, w której mówiący, reagując na dorosłe uwagi swojego rozmówcy, zwraca się do

${ }^{35}$ E. Goffman, Człowiek w teatrze życia codziennego, tłum. H. Datner-Śpiewak, P. Śpiewak, Warszawa 2000 , s. $140-143$.

${ }^{36}$ Ibidem, s. 141. 
niego w sposób właściwy dla komunikacji między rodzicem i dzieckiem, co może prowadzić do wywołania u rozmówcy dziecinnej reakcji gniewem. Jest to więc prowokacja przybierająca formę przeciwprzeniesienia ${ }^{37}$, choć może w tym przypadku termin ten nie jest najstosowniejszy, albowiem mamy tutaj do czynienia raczej z prowokacją ze strony cynicznego mówcy, niż z reakcją na przeniesienie uobecniające się w zachowaniu audytorium. Interesującym tropem, który być może pozwoliłby lepiej zrozumieć relację między cynicznym mówcą a jego słuchaczami, byłoby potraktowanie zabiegu modulacji cynicznej jako czegoś na kształt quasi-przeniesienia, w którego toku cynik rzutuje na audytorium pewne treści psychiczne, wywołując jednocześnie reakcję przeciwprzeniesieniową, przybierającą formę dziecinnego buntu wobec tonu, przy pomocy jakiego mówca cyniczny komunikuje się ze swoimi rozmówcami. W tym punkcie stajemy na niebezpiecznym rozdrożu między retorycznym i psychoanalitycznym rozumieniem praktyki dyskursu cynicznego. Z retorycznego punktu widzenia mówca cyniczny jest tym, który świadomie dokonuje prowokacji mającej na celu wywołanie dziecinnego buntu u swojego audytorium, który następnie powinien doprowadzić do próby przekształcenia relacji rodzic-dziecko (fachowiec-dyletant) w relację dorosły-dorosły (mistrz-uczniowie). W ten sposób mogą zostać otwarte kanały komunikacyjne zablokowane przez skrzyżowaną relację przeciwprzeniesieniową, która przerywa komunikację i zmusza strony aktu komunikacyjnego do uzgodnienia wektorów komunikacji ${ }^{38}$. Relacja rodzic-dorosły rozwiązuje się do relacji dorosły-dorosły.

\section{Cyniczny kontrideał}

Aby rozjaśnić ten aspekt dyskursu cynicznego, trzeba zwrócić uwagę na rolę, jaką odgrywa w nim relacja między mówcą cynicznym a jego ideowymi przeciwnikami. Relacja ta uzupełnia dwustronną relację między mówcą a jego audytorium i zmusza nas do wzbogacenia schematu retorycznej relacji między cynicznym mówcą i jego publicznością o nowy człon, do którego mówca z konieczności musi się odnosić. W przykładach przez nas omawianych rolę tę przyjmuje na siebie Sokrates, do którego odnoszą się Kallikles i Trazymach, stając przed swoimi słuchaczami. Dla zrozumienia fenomenu mowy cynicznej konieczne jest zwrócenie uwagi na dwa zasadnicze aspekty postawy, jaką przyjmuje Sokrates wobec swoich przeciwników. O jednej już wspomniałem, ukazując Sokratesa jako moralistę, który stara się dokonać przekształceń semantycznych w obrębie języka moralności, a które to starania udaremnia mówca cyniczny, formułujac paradoksy cyniczne. Drugim istotnym aspektem postawy Sokratesa jest ironia, z jaką traktuje wywody cynika, która każe mu sprowadzać cyniczne wywody komicznego absurdu. Oto w reakcji na sformułowaną przez Trazymacha definicję sprawiedliwości, zgodnie z którą sprawiedliwe jest to, co służy silniejszemu, Sokrates pyta, czy sprawiedliwa jest wołowina, której

${ }^{37}$ E. Berne, W co graja ludzie. Psychologia stosunków międzyludzkich, tłum. P. Izdebski, Warszawa 2004, s. 23 .

38 Ibidem, s. 22.

Studia Philosophica Wratislaviensia 14, z. 4, 2019

(C) for this edition by CNS 
jedzenie dobrze służy zwycięzcy w zawodach pięściarskich ${ }^{39}$. Podobnie, kiedy Kallikles stwierdza, że ten, kto silniejszy powinien mieć więcej od tego, kto słabszy, Sokrates wyciąga stąd wniosek, że może tłum powinien mieć najwięcej, bo przecież tłum fizycznie jest silniejszy od jednostek albo może ten, kto silniejszy powinien mieć więcej butów albo sukien ${ }^{40}$.

Reakcje obydu mówców cynicznych na tę Sokratesową ironię są podobne. Obaj reagują złością, zarzucają przeciwnikowi nieszczerość intencji. „Bo ty jesteś obrzydliwiec, Sokratesie — powiada [Trazymach] — i bierzesz myśl z tej strony, z której byś ją najgorzej mógł okaleczyć" ${ }^{41}$. Kallikles zaś w reakcji na spór Sokratesa z Polosem stwierdza: „Ty, istotnie, Sokratesie, lubisz ciągnąć do takich ciężkich i dobrych dla tłumu efektów, mówiąc, że prawdy szukasz, efektów, które z natury nie są piękne, tylko wedle prawa opinii"42. W obu przypadkach mamy do czynienia z sytuacją agonu, w której dwaj mówcy rywalizują z sobą na oczach publiczności i choć w każdym z przypadków mamy do czynienia z publicznością innego rodzaju, cel mówcy cynicznego się nie zmienia. Jego przeciwnik jest tym, na którego w pierwszej kolejności zostaje wyprojektowana tożsamość naiwnego i dziecinnego w swojej postawie życiowej dyletanta. To Sokrates, zgodnie ze słowami Trazymacha, potrzebuje niańki, aby wycierała mu zasmarkany nos ${ }^{43}$. To on jest podstarzałym darmozjadem, który zabawia się jak dziecko filozoficznym pustosłowiem $^{44}$. Stosunek mówcy cynicznego do jego przeciwnika jest kluczowy dla prowadzonej przez tego pierwszego gry identyfikacji, w której uczestnicy dyskursu przymierzają kolejne maski, a która ma prowadzić do przejścia publiczności na stronę cynicznego mistrza w fachu. Posłużenie się pojęciem przeciwprzeniesienia do opisu relacji między uczestnikami agonu daje nam wskazówkę, dzięki której możemy rzucić nieco więcej światła na głębszą strukturę motywacyjną, jaka skrywa się za schematem perswazyjnym dyskursu cynicznego, co z kolei pozwoli nam zrozumieć mechanizmy, które decydują o skuteczności zabiegów cynicznego mówcy. Zabieg modulacji cynicznej można w tym kontekście traktować jako grę, w której cynik dokonuje symbolicznego obnażenia porządku symbolicznego uobecnionego w osobie filozofa moralisty poprzez wskazanie na jego bezradność i praktyczną niemoc. Cyniczny mówca, kierując swój atak przeciwko porządkowi symbolicznemu reprezentowanemu przez moralistę, wskazuje na sferę praktycznego działania jako na punkt oparcia dla roztropnej praktyki życiowej. Dbanie o swój własny interes oparte na nieuprzedzonym i obiektywnym oglądzie rzeczywistości społecznej i praktycznych regułach skutecznego działania umożliwia jednostce uwolnienie się od ograniczeń, jakie nakłada na nią porządek symboliczny. Przyjmując autoidentyfikację jako chłodnych i skupionych na życiowym konkrecie fachowców, publiczność może zrzucić z siebie ciężar obowiązków wyznaczanych przez prawo moralne i oddać się autoafirmacji swojej nowej tożsamości.

\footnotetext{
39 Platon, Państwo, 338c s. 37.

40 Platon, Gorgiasz, 490d-491c, s. 403

41 Platon, Państwo, 338d, s. 37

42 Platon, Gorgiasz, 482e s. 393.

43 Platon, Państwo, 343a, s. 45.

${ }^{44}$ Platon, Gorgiasz, 485d, s. 397
} 
Trójczłonowa relacja, na której zbudowany jest dyskurs cyniczny, określa właściwy dla tego rodzaju perswazji punkt oparcia, którym jest etos fachowca. Michel Foucault, wyróżniając trzy formy wypowiadania prawdy (véridiction), uznał ethos za punkt oparcia właściwy dla cynickiej parezji ${ }^{45}$, zdecydowanie odróżniając go od mowy eksperckiej (technicien), dla której właściwym punktem odniesienia

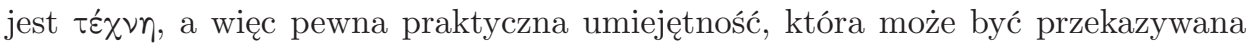
uczniom, a której reguły przekazywane są z pokolenia na pokolenie ${ }^{46}$. Próbujacc umieścić w powyższym schemacie sposób przemawiania, który określiłem dyskursem cynicznym, musimy dojść do wniosku, że łączy on w sobie zarówno odwołanie do pewnej praktycznej umiejętności, jak i do pewnego ethosu. W rzeczy samej, patrząc z tej perspektywy, rozróżnienie dokonane przez francuskiego myśliciela wydaje się sztuczne, gdy bowiem fachowiec staje przed publicznością złożoną z dyletantów, nie może, starając się ich przekonać do przejścia na swoją stronę, odwoływać się do reguł sztuki, której ci nie mogą znać i do których skuteczności mogą nie mieć przekonania. Musi on raczej pokazać siebie samego jako fachowca reprezentującego pewien właściwy dla przyjętej persony ogólny sposób myślenia i postępowania, w którym mieści się rzetelność, rzeczowość i trzeźwość konieczne dla skutecznego uporania się ze stojącymi przed nim trudnościami, a więc jako reprezentanta pewnego ethosu. Wymienione cechy charakteru można określić mianem cnót właściwych dla praktyki fachowego działania. Byłoby to w pełni zgodne ze sposobem rozumienia tych terminów, jaki zaproponował Alisadair MacIntyre:

Przez ,praktykę" - pisze A. MacIntyre - mam na myśli wszelką spójną i złożoną formę społecznie ustanowionej, kooperatywnej działalności ludzkiej, poprzez którą dobra wewnętrzne wobec tej działalności są realizowane w procesie dążenia do realizacji wzorców doskonałości, które są charakterystyczne dla tej formy działalności i które po części ją definiują ${ }^{47}$.

Przez cnotę rozumie on natomiast ludzką cechę, „której posiadanie i przestrzeganie umożliwia nam osiąganie dóbr wewnętrznych wobec praktyk, jej brak natomiast osiąganie tych dóbr skutecznie nam uniemożliwia"48. Zatem mówca cyniczny reprezentuje sobą cnoty w rozumieniu MacIntyre'a, zaś działalność fachowca jest w tym rozumieniu ową praktyką, stanowiącą właściwy dla nich kontekst społeczny. W pojęciu Greka pojęcie fachowości zawierało w sobie przede wszystkim odniesie-

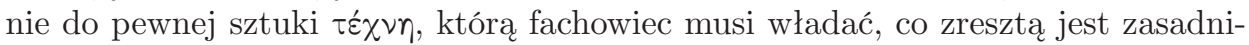
czym problemem, jaki w omawianym dialogu stawia przed Gorgiaszem Sokrates. Ten pierwszy musi określić, jakiego rodzaju sztuką jest sztuka przemawiania ${ }^{49}$. Jest to jednak tylko jeden z aspektów greckiego rozumienia fachowości. Termin dēmiourgós zawiera bowiem również odniesienie do społecznego wymiaru działalności fachowca, którego sztuka powinna służyć ludowi ${ }^{50}$. Jako taki onuıouprós

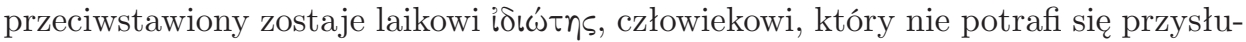

${ }^{45}$ M. Foucault, The Courage of the Truth, tłum. G. Burchell, Nowy Jork 2008, s. 25.

46 Ibidem, s. 24.

47 A. MacIntyre, Dziedzictwo cnoty. Studium z teorii moralności, tłum. A. Chmielewski, Warszawa 1996, s. 338 .

48 Ibidem, s. 344.

49 Platon, Gorgiasz, 452d-e s. 349.

50 T. Sinko, Zarys historii literatury greckiej, t. 1, Warszawa 1959, s. 282. 
żyć rodakom swoją sztuką, albowiem takową nie włada ${ }^{51}$. Ten drugi aspekt znaczeniowy greckiego terminu określającego fachowca wyzyskują w swoich mowach Kallikles i Trazymach. Obaj ukazują Sokratesa jako laika, który ani sobie, ani innym nie może w niczym pomóc. Odrzucając twierdzenie Sokratesa, jakoby lepiej było doznawać krzywd niż je wyrządzać, Kallikles stwierdza:

to [...] nie jest stan godny człowieka: doznawanie krzywd, tylko niewolnika jakiegoś, któremu by lepiej umrzeć, niż żyć, którego krzywdzą i poniewierają, a on nawet nie potrafi dać sobie rady, ani pomóc komuś drugiemu, na którym by mu zależało ${ }^{52}$.

Skojarzenie niefachowca i niewolnika, którym w cytowanym fragmencie posługuje się sofista, ma również swoje źródło w kulturze i języku starożytnych Greków, dla których określenie iócஸ́tns przywodziło skojarzenie ze stanem bezdusznego narzędzia w ręku mocniejszego. Można się tutaj posłużyć przykładem zaczerpniętym z Lukianowego Aleksandra albo rzekomego proroka, który bezwolnych posłańców owego proroka określa mianem dobrodusznych niewolników ${ }^{53}$. Sokrates uosabia dla cynicznych sofistów takiego właśnie bezwolnego i bezużytecznego dyletanta, którego działalność jest, jeśli nie szkodliwa, to przynajmniej bezwartościowa z praktycznego punktu widzenia.

Cynik buduje zatem opozycję między sobą i swoją publicznością z jednej strony, a naiwnym i bezradnym moralistą, którego rolę przyjmuje w omawianych tekstach Sokrates, z drugiej. Owo przeciwstawienie przybiera często formę buntu przeciwko wszelkiej działalności intelektualnej, która nie jest odniesiona bezpośrednio do praktyki życiowej. Ten element strategii cynicznego mówcy określam mianem a n ty intelektualizmu cynicznego. W kontekście sporów, jakie toczyli z Sokratesem Trazymach i Kallikles, efekt, o którym mowa, zostaje wzmocniony przez przeciwstawienie pozbawionej złudzeń postawy sofistów moralizmowi Sokratesa, co oznacza również przyjęcie postawy antyfilozoficznej, wyrażającej się w trzeźwym praktycyzmie. Podobnie jak Trazymach Kallikles zwraca się do swojego rozmówcy z lekceważeniem. Kontekst narracyjny, w którym umieszczona została ta druga rozmowa, różni się od tego, z którym mieliśmy do czynienia w Państwie. Publiczność przyglądająca się rozmowie Kalliklesa i Sokratesa składa się bowiem już nie z przyjaciół tego ostatniego, ale z młodych sofistów, uczniów Gorgiasza. Kallikles skupia się na samym Sokratesie i, przydając mu nieatrakcyjną tożsamość filozoficznego mędrka, odciąga od niego i tak być może niechętne mu audytorium. Mamy tu zatem do czynienia z rozgrywką bardziej złożoną. Cyniczny mówca nie zwraca się do audytorium wprost. Przedstawia samego siebie jako pozbawionego złudzeń i trzeźwo myślącego mistrza w sztuce retorycznej, Sokratesa zaś z pobłażaniem poucza i napomina. Filozoficzne rozmyślania, jakim poświęca czas syn Fajanrety, traktuje jako dziecinną zabawę, której powinni się oddawać

${ }^{51}$ Przeciwstawienie to odnajdujemy w Platońskim Protagorasie (327c), a także w Ionie, gdzie So-

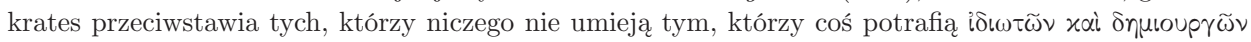
(531c).

52 Platon, Gorgiasz, 483b, s. 394.

${ }^{53}$ Zob. Lukian z Samosat, Aleksander albo rzekomy prorok, [w:] idem, Dialogi, tłum. M.K. Bogucki, t. 2, XXX, 1991, s. 232 . 
tylko ci, którzy są jeszcze za młodzi na uczestniczenie w życiu publicznym, a które człowiek dojrzały musi porzucić:

filozofia to, wiesz, Sokratesie, rzecz wcale miła, jeśli się nią ktoś za w miarę pobawi za młodu. A jeśliby kto w niej tkwił dłużej niż potrzeba, to gotowe zepsucie człowieka. Bo gdyby nawet miał naturę dzielną, to jeśliby z by zbyt długo w życiu filozofował, żadną miarą nie nabędzie doświadczenia w niczym z tych rzeczy, z którymi musi być obyty każdy, kto ma zostać dobrym i pięknym, i zaszczytnie znanym obywatelem. Nie nabiera się przecież żadnego doświadczenia w zakresie praw, wedle których płynie życie w państwie, nie nabiera się wprawy w słowach, których potrzeba w obcowaniu i w stosunkach i prywatnych, i publicznych — w ogóle: znajomość życia zanika wtedy w zupełności. I niech się który weźmie do jakiejkolwiek czynności publicznej czy prywatnej, robi się śmieszny, zupełnie tak samo, jak wyobrażam sobie, śmieszny będzie polityk, gdyby przyszedł na wasze dyskusje i roztrząsania. [...] Otóż mnie się zdaje, że najsłuszniej jest skosztować jednego i drugiego. Filozofii o tyle, o ile ze względu na wykształcenie pięknie jest mieć z nią coś, i nic złego, jeżeli chłopak filozofuje. Ale jeśliby starszy człowiek ciągle jeszcze filozofował, to robi się rzecz śmieszna, Sokratesie, i na mnie człowiek filozofujący robi zupełnie takie wrażenie, jak ten, co się jąka i sepleni i potrzebuje zabawki, to przyjemnie mi i wydaje mi się to miłe i szlachetne, swobodne i odpowiednie do wieku dziecka; przeciwnie jak słyszę dziecko, które rozmawia wyraźnie i jasno, mam jakieś przykre wrażenie, to mi razi uszy i wydaje mi się czymś wymęczonym, czymś niewolniczym. Otóż, kiedy ktoś usłyszy, jak się dojrzały mąż jąka i sepleni, albo go zobaczy z zabawką w ręku, to się śmieszną rzeczą wydaje; niegodną mężczyzny, a godną kijów ${ }^{54}$.

Fachowość mówcy przeciwstawiona zostaje pustemu i szkodliwemu mędrkowaniu. Przez słowa Kalliklesa przebija surowy praktycyzm, na którego podstawie mówca cyniczny pozbawia znaczenia wszelką działalność, która nie pozwala rozwiązywać najbardziej palących problemów codziennego życia. Na pogardę zasługuje w jego oczach filozofia, która ani nie daje dachu nad głową, ani nie pozwala radzić sobie na agorze czy w sądzie. Ten przeciwstawiany moralizmowi wzorzec fachowca o wielkiej mocy można określić mianem k o n tri d e a ł u c y n i c z n e g o.

\section{Populizm antydemokratyczny, arystokratyzm ludowy}

Trudno nie dostrzec podobieństwa, które łączy antyfilozoficzną postawę Kalliklesa i Trazymacha z antyintelektualizmem mówców ludowych, tak wyraziście sportretowanych przez Tukidydesa w osobie Kleona — przywódcy ateńskiego stronnictwa demokratycznego podczas jednego z epizodów wojny peloponeskiej, jakim było uśmierzenie przez Ateny buntu, który przeciwko ich dominacji podnieśli mieszkańcy Mityleny. Ów Kleon namówił Ateńczyków do krwawej pacyfikacji rebelii w Mitylenie i wymordowania wszystkich jej mieszkańców. Następnego dnia jednak zgromadzenie ludowe, kierując się skrupułami natury moralnej, postanowiło cofnąć powziętą wcześniej decyzję, co wywołało spór, w którym głównymi aktorami byli wspomniany już Kleon oraz niejaki Diodotos, który ostatecznie odwiódł Ateńczyków od krwawej zemsty na wszystkich Miteleńczykach. Mowa, którą przy tej okazji wygłasza Kleon, stanowi dobry przykład mowy cynicznej i pozwala rzucić nieco światła na praktycyzm głoszony przez Trazymacha i Kalliklesa. Kleon jest mówcą ludowym, a jego praktycyzm wyraża się w potępieniu wszelkiej kultury wyższej w imię ludowej zaradności i siły charakteru: „brak wykształcenia połą-

${ }^{54}$ Platon, Gorgiasz, 484c-485d, s. 395-396. 
czony z siłą - mówi Kleon - charakteru większy pożytek państwu przynosi niż wiedza bez charakteru i że prości ludzie najczęściej lepiej rządzą swymi państwami niż uczeni"s5.

Populizm Kleona zwraca się już nie przeciwko filozofii, lecz przeciwko każdej formie kultury opartej na magii słowa mówionego. Traktuje on tak samo wszystkich jej przedstawicieli, widząc w nich mówców uwodzących lud modnym pustosłowiem. Wyrzuca swojej publiczności, że ulegając powabowi nowości i modom intelektualnym, traci z pola widzenia praktyczne wymogi życia i fakty, za których przeoczenie może słono zapłacić:

Przy takich turniejach krasomówczych państwo oddaje nagrody innym, a samo naraża się na niebezpieczeństwo. Winni zaś temu jesteście sami; jesteście bowiem złymi sędziami tego turnieju, bo przywykliście być widzami mów, a słuchaczami czynów; oceniacie przyszłość na podstawie pięknych możliwości, jakie malują przed waszymi oczyma mówcy, a przeszłość na podstawie tego, jak ją zręczni mówcy zgania, nie tyle dając wiarę oczywistym faktom, ile słowom ${ }^{56}$.

Wiąże się z tym paradoksalny, bo ludowy antydemokratyzm Kleona, który jako przedstawiciel partii demokratycznej jest jednocześnie sceptyczny wobec możliwości politycznych państw rządzonych demokratycznie: „Niejednokrotnie już i przedtem sądziłem - mówi Kleon — że państwo demokratyczne nie jest zdolne do panowania nad innymi, teraz zaś szczególnie jasno to widzę, patrząc na wasz obecny żal nad Mityleńczykami"'57.

W tym miejscu spotykają się sposób myślenia Kleona z wizją polityki, jaką reprezentuje Kallikles. Ten ostatni przeciwstawia Sokratesowemu moralizmowi ideał silnej jednostki, która nie oglądając się na skrupuły moralne, potrafi dokonać wielkich czynów, troszcząc się jedynie o to, aby czerpać jak najwięcej dla siebie. Na przeszkodzie takiej silnej jednostce staje tłum słabeuszów, którzy robią wszystko, żeby ją obezwładnić i zmusić do posłuszeństwa. Narzędziem owego obezwładniania jest przede wszystkim mowa: ,już za młodu je bierzemy, jak lwięta, poddajemy urokowi pięknych słów, czarem kuglarskich sztuczek ujarzmiamy je, mówiąc, że trzeba mieć tyle, co drudzy, i to jest to, co piękne i co sprawiedliwe" ${ }^{\text {"58 }}$. Ten, kto ma siłę, będzie umiał zerwać z siebie utkane ze słów pęta i zdobyć dla siebie panowanie, przywracając w ten sposób naturalny porządek rzeczy, na który powoływali się również posłowie ateńscy na Melos, a w którym to, co silne panuje, a to, co słabe musi ulegać ${ }^{59}$. Słuchając słów Kalliklesa, nie sposób nie pomyśleć - a skojarzenie to z pewnością przychodziło na myśl również współczesnym Platonowi czytelnikom jego dzieł - o Alkibiadesie, słynnym enfant terrible polityki ateńskiej, który wydaje się wcieleniem Kalliklesowego ideału. On to raz po raz zrywał krępujące go więzi zależności i zobowiązań, zmieniał sojusze, a jedynym przewodnikiem była dla niego własna ambicja i duma potomka wielkiego rodu. W jednym z najbardziej interesujących fragmentów rozmowy między Sokratesem i Kalliklesem filozof zwraca

\footnotetext{
55 Tukidydes, Wojna peloponeska, tłum. K. Kumaniecki, Wrocław-Warszawa-Kraków 2004, s. 213.

56 Ibidem, s. 214.

57 Ibidem, s. 212.

58 Platon, Gorgiasz, 483e-484a, s. 395.

${ }^{59}$ Ibidem, 484a, s. 395.
} 
się do swojego rozmówcy z uwagą, która pozwala rzucić nieco światła na sposób, w jaki mówca cyniczny buduje relację z publicznością:

ja i ty przeżywamy jeden i ten sam stan wewnętrzny: każdy z nas kocha się w dwóch. Ja w Alkibiadesie, synu Kleiniasa, i w filozofii, a ty w Demosie ateńskim i w synu Pyrilampa. Otóż nieraz uważam, że choć jesteś człowiek tęgi, to jednak, cokolwiek powie twój ukochany i jakkolwiek powie, że się rzeczy mają, ty nie umiesz powiedzieć, że nie, tylko się kręcisz na wszystkie strony. Na zgromadzeniu, jeżeli coś mówisz, a Demos ateński powie, że nie tak jest, obracasz się na miejscu i mówisz to, czego on chce, a w stosunku do chłopaka Pyrilampa, tego pięknego, znowu czegoś podobnego doznajesz. Chęciom i słowom kochanków nie umiesz się sprzeciwić, tak, że gdyby ktoś kiedy słyszał to, co pod ich wpływem mówisz, i dziwiłby się, jakie to głupie, ty byś mu może powiedział, gdybyś chciał prawdę mówić, że jak długo ktoś twoich kochanków nie zmusi, żeby tak mówić przestali, to i ty nie przestaniesz tak mówić60.

Mówiąc o Kalliklesie jako o kochanku ateńskiego i Pyrliampowego Demosa, wskazuje na dwuznaczność postawy ateńskiego polityka, który choć odwołuje się do ideału arystokratycznej kalokagatii, w swoich poglądach schlebia ludowi ateńskiemu, który podobnie jak Demos, syn Pyrilampa, znany jest nie tylko ze swojego powabu, lecz także z głupoty ${ }^{61}$. Kallikles zatem wysławia ideały arystokratyczne, których ucieleśnieniem był Alkibiades, ale jest kochankiem ludu ateńskiego, podczas gdy Sokrates jest kochankiem samego Alkibiadesa. Postawa Kalliklesa jest zatem dwuznaczna, a nawet paradoksalna, podobnie jak postawa Tukidydesowego Kleona. Obaj politycy głoszą ideały antydemokratyczne, którymi schlebiają gustom ludu. Potępiając jego gnuśność, stawiają przed nim ideał arystokratycznej

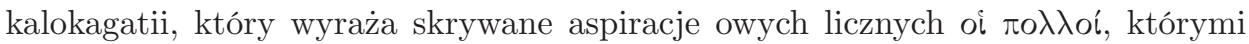
Kallikles wydaje się gardzićc ${ }^{2}$. W ten sposób odsłania się przed nami trzeci wymiar mowy cynicznej, który czyni ją tak bardzo atrakcyjną dla publiczności. Mówca cyniczny ma do zaoferowania nie tylko ideał racjonalnej i pozbawionej złudzeń fachowości, lecz także kuszącą wizję wyniesienia ponad pogardzany motłoch i spełnienia. Oba te ideały wydają się zresztą łączyć z sobą, czego świadectwa możemy znaleźć w dialogach Platona. Oto w drugiej księdze Państwa Glaukon, konstruując obraz człowieka doskonale niesprawiedliwego, przydaje mu rysy Trazymachowego mistrza w sztuce:

niesprawiedliwy niech tak postępuje, jak dzielni zawodowcy. Na przykład sternik najlepszy albo lekarz tak samo zawsze rozróżnia to, co nie jest możliwe w jego sztuce, i to, co jest możliwe. I do jednego rękę przykłada, a drugiego nie tyka. A jeszcze, gdyby mu się tam gdzieś noga przypadkiem podwinęła, on potrafi to naprawić ${ }^{63}$.

Podobnie w Hippiaszu mniejszym Sokrates, chcąc doprowadzić do absurdu charakterystyczne dla nauczania sofistów pojęcie cnoty, która polega na umiejętnym radzeniu sobie w sytuacjach życiowych, pokazuje, że człowiekiem dobrym w tym właśnie znaczeniu jest ktoś bezwzględnie i z premedytacją dokonujący nawet czynów zbrodniczych:

\footnotetext{
${ }^{60}$ Ibidem, 481e-482a, s. 392.

61 Zob. D. Nails, A Prosopography of Plato and Other Socratics, Cambridge 2002, s. 124.

${ }^{62}$ Platon, Gorgiasz, 483b, s. 394.

${ }^{63}$ Platon, Państwo, 260a-261b, s. 70.
} 
Ci, co ludziom szkodzą i krzywdzą ich, i oszukują, i uchybiają prawu rozmyślnie, a nie mimo woli, ci mi się wydają lepsi niż ci, co mimo woli. Niekiedy znowu zdaje mi się wprost przeciwnie; więc błąkam się na tym punkcie; oczywista dlatego, że nie mam wiedzy. Ale teraz, w tej chwili, jakby mnie coś napadło i wydają mi się rozmyślni przestępcy lepsi pod jakimś względem od mimowolnych ${ }^{64}$.

Ostatecznie, formułując ten paradoks, Sokrates w znaczący sposób wiąże go z sofistycznym ideałem fachowości, ukazując, do jakich konsekwencji prowadzi hołdowanie ideałowi zimnej i pozbawionej złudzeń eksperckości:

Sokrates: Zatem dobrego człowieka cechuje to, że występki popełnia umyślnie, a lichego to, że mimo woli, skoro dobry mąż dobrą ma duszę.

Hippiasz: A tak, ma przecież.

Sokrates: Więc, jeśli kto umyślnie występki popełnia i brzydko, i niesprawiedliwie postępuje, Hippiaszu, jeśli tylko istnieje ktokolwiek taki, to nie będzie nikt inny, tylko człowiek dobry ó ảräós.

Hippiasz: Sokratesie: ja się nie umiem z tobą na to zgodzić.

Sokrates: Ani nawet ja sam ze sobą, Hippiaszu. Tylko tak nam to teraz przynajmniej koniecznie wypadło z rozważań. Ja tak, wiesz, jakem dawno powiedział, błąkam się w tych rzeczach tędy i owędy, i nigdy mi się jedno i to samo nie wydaje. Ale, że ja się błąkam, to nic dziwnego, albo inny tam jaki

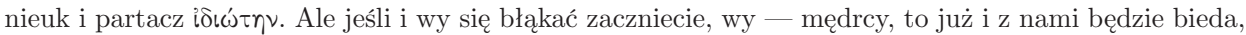
jeżeli nawet do was człowiek przyjdzie, a błąkać się nie przestanie ${ }^{65}$.

Wysiłki Sokratesa zarówno w Hippiaszu mniejszym, jak i na kartach Gorgiasza skupiają się wokół próby obalenia ideału fachowości cynicznej, który stanowi istotny przedmiot cynicznego kuszenia publiczności. Fachowość sofisty, którą Gorgiasz chciałby widzieć wielką, umniejszona zostaje do rzędu jednego z wielu kunsztów, z których żaden nie może uczynić lepszym człowieka z nich korzystającego, a może pomóc mu jedynie w uratowaniu tego, co samo z siebie nie jest żadnym dobrem i o co człowiek prawy dbać nie powinien:

A jeżeli ta [tj. sztuka pływania - M.P.] wydaje ci się małą, ja ci przytoczę większą on niej: umiejętność sternika, która nie tylko życie ratuje, ale i ciało, i mienie; z największych niebezpieczeństw; zupełnie jak retoryka. A jednak ona jest skromna i przyzwoita; nie zadziera nosa, nie robi wielkich min, jak gdyby nie wiadomo jakich dzieł dokazywała, tylko dokonawszy tego samego, co wymowa sądowa, jeżeli kogo z Eginy tutaj cało przyniesie, bierze za to, zdaje mi się, dwa obole, a jeśli z Egiptu albo z Pontu, to jeśli już bardzo dużo chce za to tak wielkie dobrodziejstwo, bo jak mówię, przenosi cało i człowieka samego, i dzieci, i pieniądze, i kobiety wysadza w porcie na ląd — bierze za to: dwie drachmy. I ten sam, który posiada umiejętność i który tego dokazał, wysiada z okrętu i chodzi koło niego nad brzegiem morza z miną bardzo skromną. Uważam, że umie rachować i miarkuje, że to nie jest jasna rzecz, którym gościom oddał przysługę, nie pozwalając im się utopić, a którym zaszkodził. On wie, że ich ani o włos lepszymi nie wysadził, aniżeli wsiedli na okręt; ani co do ciała, ani co do duszy. Więc myśli sobie, że jeśli kogoś wielkie i nieuleczalne choroby trapiły na ciele, a nie utopił się po drodze, ten jest wielki nieszczęśnik, że nie umarł; temu sternik żadnej nie oddał przysługi. A jeśli ktoś w tym, co jest od ciała cenniejsze, w duszy liczne choroby nosi i nieuleczalne, takiemu niby to warto żyć i takiemu by się przysłużył, gdyby go z morza, czy z sądu, czy skąd tam inąd wyratował? On przecież wie, że podłemu człowiekowi lepiej nie żyć. Bo złe musi być jego życie ${ }^{66}$.

Sokrates uderza tutaj w samo serce cynicznego sposobu przemawiania. Jest nim zaś oferta, jaką cynik przez swój sposób mówienia składa publiczności: jeśli staniesz po mojej stronie, będziesz jednym z tych, którzy potrafią ocalić to, co

\footnotetext{
${ }^{64}$ Platon, Hippiasz mniejszy, 372d, s. 144.

${ }^{65}$ Ibidem, 376b-c, s. 152-153.

${ }^{66}$ Platon, Gorgiasz 511c-512a, s. 432-433.
} 
każdy uważa za największe dobro dla siebie, a tym jest żyć i mieć w życiu jak najwięcej. Ideał, jaki stawia przed swoją publicznością mówca cyniczny, stanowi wyraz ukrytych aspiracji członków publiczności. Stając po stronie cynika, każdy z nich może poczuć się wyniesiony ponad pozostałych. Z tego właśnie powodu retoryczna identyfikacja publiczności z cynikiem najczęściej ma charakter milczący, albowiem zbiorowe przyklaśnięcie ideałowi cynicznemu musiałoby wprawiać w zakłopotanie. Oznaczałoby ono bowiem przyznanie, że ideał wynoszącej się ponad ogół jednostki jest w istocie ideałem podzielanym przez oi ro $\lambda \lambda o$ ó, którymi cynik pogardza. Sokrates zestawia ten cyniczny ideał z wizją człowieka dobrego, który dba o to jedynie, aby jego dusza była jak najlepsza, resztę zaś pozostawiając bogom do rozporządzenia, wobec wyroków których nawet najwięksi fachowcy muszac pozostać bezsilni ${ }^{67}$.

\section{Uwagi końcowe}

Mowa cyniczna zatem rozpoczyna się i kończy paradoksem. Jest to nieusuwalna cecha wszelkich przejawów fenomenu cyniczności. Dyskurs cyniczny pozbawiony pewnej dwuznaczności straciłby cały swój powab, który bierze się z dwojakiej postawy, jaką mówiący cynik przyjmuje wobec swojego audytorium i z dwojakiej propozycji, jaką składa on swoim słuchaczom. Z jednej strony przyjmuje rolę surowego cenzora, który obnaża naiwność swoich interlokutorów i przeciwstawia się jej jako reprezentant ethosu fachowości. Z drugiej zaś stara się schlebiać gustom swoich słuchaczy, sugerując, że mogą oni przystąpić do reprezentowanego przezeń cechu skupiającego tych, którzy jak się wyraził inny mówca cyniczny, „znają się na rzeczy"68 i przez to zostać wyniesionymi ponad otaczający ich tłum bezmyślnych oi ro入入oí. Kallikles, schlebiając tłumowi, wychwala Alkibiadesa. Kleon jako przywódca ludowy potępia demokrację jako bezsilną i w decydujących chwilach niezdolną do działania. Mowa cyniczna zatem sama jest paradoksem. Cyniczny mówca głosi ideał arystokratyczny na użytek motłochu. Rości sobie prawo do fachowości, a schlebia gustom dyletantów. Cynik wygłasza mowy, w których potępia tych, którzy czarem słowa chcą zjednać sobie przychylność publiczności.

Posługując się kategoriami zaczerpniętymi z psychoanalizy Lacanowskiej, można powiedzieć, że cyniczne mówienie jest ze swej natury czynnością perwersyjną: cynik posługuje się językiem, ale odmawia mu wszelkiej wartości jako narzędziu oszustwa. Jako wyraz perwersyjności cyniczne mówienie domaga się rozwiązania, które będzie oznaczać uznanie roszczeń struktur symbolicznych wyrażających się poprzez język lub zupełne odrzucenie wymogów stawianych przez to, co symboliczne, a co ogólnie określane bywa mianem kultury i oddania się działaniom mającym za jedyny cel zaspokojenie własnych pożądań. Adwokatem tego pierwszego rozwiązania jest w omawianych tekstach Sokrates, który samego siebie czyni obrońcą tego, co rozumne, czyli symbolicznie ważne, przed inwazją ze strony bezrozumnego pragnienia. Drugie ze wskazanych rozwiązań reprezentuje Kallikles w swojej wizji

\footnotetext{
${ }^{67}$ Ibidem, 512d-e, s. 433.

${ }^{68}$ N. Machiavelli, Książe, tłum. Cz. Nanke, [w:] idem, Wybór pism, Warszawa 1972, s. 189.
} 
człowieka sprawiedliwego z natury. Dwuznaczność tkwiąca w samym pojęciu sprawiedliwości naturalnej wciąga cynika w grę znaczeń, w którą stara się on wplątać również Sokratesa, zmuszając go do odsłonięcia ostatecznych podstaw, na jakich opiera swój moralizm, a którymi są wiara religijna i wizja sądu bożego ${ }^{69}$.

Ostatecznie paradoks, który jest dla cynicznego mówcy punktem wyjścia procesu modulacji cynicznej, sam stanowi wyraz nieufności wobec jezzyka jako medium transmisji treści kulturowych, szczególnie w tej ich warstwie, która stanowi symboliczny fundament moralności. Sama moralność i operujący w jej obrębie filozof moralista są dla cynika przedmiotem szczególnej niechęci i to wokół nich krystalizuje się to, co można określić mianem dyskursu cynicznego.

\section{Bibliografia}

Arystoteles, Metafizyka, tłum. K. Leśniak, Warszawa 1984.

Arystoteles, O dowodach sofistycznych, [w:] idem, Topiki. O dowodach sofistycznych, tłum. K. Leśniak, Warszawa 1978.

Berne E., W co graja ludzie. Psychologia stosunków międzyludzkich, tłum. P. Izdebski, Warszawa 2004.

Burke K., Attitudes toward History, Berkeley 1984.

Burke K, Rhetoric of Motives, Los Angeles-Berkeley 1969.

Colli G., Narodziny filozofii, tłum. S. Kasprzysiak, Warszawa-Kraków 1991.

Epiktet, Diatryby. Encheiridion, tłum. L. Joachimowicz, Warszawa 1961.

Foucault M., The Courage of the Truth, tłum. G. Burchell, Nowy Jork 2008.

Głowiński M., O mówieniu cynicznym, „Etyka” 37 (1997).

Goffman E., Człowiek w teatrze życia codziennego, tłum. H. Datner-Śpiewak, P. Śpiewak, Warszawa 2000.

Hyde M.J., Paradox: The Evolution of figure of Rhetoric, [w:] Rhetoric 78: Proceedings of Theory of Rhetoric: An Interdisciplinary Conference, R.L. Brown Jr., M. Steinmann Jr. (eds.), Minneapolis 1979.

Levine D.B., Poetic Justice: Homer's Death in the Ancient Biographical Tradition, „The Classical Journal” 98 (2002/2003).

Liddell H.G., Scott R., A Greek-English Lexicon, Oxford 1996.

Lukian z Samosat, Aleksander albo Rzekomy prorok, [w:] idem, Dialogi, tłum. M.K. Bogucki, t. 2, Wrocław 2006.

Machiavelli N., Ksiązę, tłum. Cz. Nanke, [w:] idem, Wybór pism, Warszawa 1972.

MacIntyre A., Dziedzictwo cnoty. Studium z teorii moralności, tłum. Adam Chmielewski, Warszawa 1996.

Martin R.P., The Seven Sages as Performers of Wisdom, [w:] Cultural Poetics in Archaic Greece: Cult, Performance, Politics, C. Dougherty, L. Kurke (eds.), New York-Oxford 1998.

Nails D., A Prosopography of Plato and Other Socratics, Cambridge 2002.

Platon, Gorgiasz, [w:] idem, Dialogi, tłum. W. Witwicki, t. 1, Kęty 1999.

Platon, Hippiasz mniejszy, [w:] idem, Dialogi, tłum. W. Witwicki, t. 1, Kęty 1999.

${ }^{69}$ Platon, Gorgiasz, 526c-d, s. 448. 
Platon, Obrona Sokratesa, [w:] idem, Dialogi, tłum. W. Witwicki, t. 1, Kęty 1999. Platon, Państwo, tłum. W. Witwicki, t. 1, Warszawa 2010.

Sinko T., Zarys historii literatury greckiej, Warszawa 1959.

Stevenson Ch.L., Definicje perswazyjne, tłum. M. Pietrzak, ,Studia z Historii Filozofii” 2 (2015).

Stevenson Ch.L., Ethics and Language, New Haven 1944;

Tukidydes, Wojna peloponeska, tłum. K. Kumaniecki, Wrocław-Warszawa-Kraków 2004. 